\title{
PERENCANAAN DAN STRATEGI KOMUNIKASI JARINGAN FRANCHISE WARUNG TEGAL KHARISMA BAHARI
}

\author{
Agus Hitopa Sukma ${ }^{1 *}$ dan Iswahyu Pranawukir ${ }^{2}$ \\ ${ }^{1,2}$ Institut Bisnis dan Informatika Kosgoro 1957, Jakarta. \\ *agushitopa@gmail.com
}

\begin{abstract}
In Jakarta, the image of the Tegal warung which is synonymous with the lower-class consumer segmentation has slowly begun to change, since the Kharisma Baharifranchise has begun to offer a new concept in the tegal shop business. This shop has tried digital services to improve its consumer segmentation services. The research objective is to know the planning and communication strategy of the Warung Tegal Kharisma Bahari (WTKB) franchise network in increasing consumer segmentation. The research method is descriptive qualitative and the interview process is carried out through data classification and cross check theory. The results showed that there was a dynamic communication strategy of the WTKB franchise network in increasing the resources of WTKB actors. At the initial stage the pull model is used, then the push model, followed by the pass. Pull, by accommodating all the aspirations and inspirations of WTKB actors to find a solution, while push, a cultural change communication strategy sells through the 5R messages: Concise, Neat, Clean, Careful and Diligent. Communication barriers include cultural, educational and personal aspects. While the supporting aspect is the operational field of WTKB which has been attached to all levels of society as a traditional cheap food which is a cost-effective solution.
\end{abstract}

Keywords: planning, strategy, segmentation, network, warteg (WTKB)

\begin{abstract}
Abstrak
Di Jakarta, image warung tegal yang identik dengan segmentasi konsumen kelas bawah perlahan mulai berubah, sejak adanya franchise Kharisma Bahari yang menawarkan konsep baru dalam bisnis warung tegal. warung ini telah mencoba layanan digital untuk meningkatkan layanan segmentasi konsumennya. Tujuan penelitian adalah ingin mengetahui perencanaan dan strategi komunikasi jaringan franchise Warung Tegal Kharisma Bahari (WTKB) dalam meningkatkan segmentasi konsumen. Metode penelitian yaitu deskriptif kualitatif dan proses wawancara dilakukan melalui klasifikasi data dan cross check teori. Hasil penelitian menunjukkan adanya dinamika strategi komunikasi jaringan franchise WTKB dalam meningkatkan sumberdaya pelaku WTKB. Pada tahapan awal digunakan model pull, selanjutnya model push, dilanjutkan dengan pass. Pull, dengan menampung semua aspirasi dan inspirasi para pelaku WTKB untuk dicarikan jalan solusinya, sedangkan push, strategi komunikasi perubahan budaya berjualan melalui pesan 5R: Ringkas, Rapi, Resik, Rawat dan Rajin. Hambatan komunikasi meliputi aspek budaya, pendidikan dan personal. Sedangkan aspek pendukung adalah bidang operasional WTKB yang sudah melekat pada semua lapisan masyarakat sebagai makanan murah tradisional yang menjadi solusi hemat.
\end{abstract}

Kata Kunci: perencanaan, strategi, segmentasi, jaringan, warteg (WTKB)

\section{PENDAHULUAN}

Akronim warteg sudah sangat familier di kalangan masyarakat bawah di seluruh pelosok tanah air. Meskipun warteg merupakan singkatan dari warung tegal yang merujuk pada sebuah kota di ujung barat provinsi Jawa Tengah, yakni Kota Tegal, tetapi di luar pulau
Jawa pun label warung tegal cukup dikenal sebagai warung "sederhana" dengan sajian khas kuliner Jawa Tengah dan Jawa Timur.

Citra warteg sebagai warungnya kalangan bawah, memang tidak dapat dielakkan, karena menu yang disajikan, desain ruang, bahkan penjualnya pun terkesan 
"sederhana" sesuai dengan situasi dan kondisi ekonomi kalangan bawah. Dengan demikian, maka untuk kalangan menengah ke atas tentu warteg tidak sesuai dengan selera mereka, bahkan mereka kerap menganggap warteg identik dengan tempat duduknya yang kotor dan kuno, sehingga ada gengsi jika harus duduk santai apalagi berlama-lama dengan pasangan atau klien.

Dalam perkembangannya, warteg stagnan dengan segmentasi konsumen kalangan bawah dan hanya sebagian kecil warteg yang berusaha meningkatkan segmentasi konsumen dengan merenovasi dan mengimprovisasi sarana fisik atau model pelayanannya. Sayangnya, hal ini hanya terjadi di sebagian kecil warteg saja, utamanya warteg yang berlokasi di area kampus, perkantoran atau lingkup food center yang tentunya dari sisi harga memang tidak semurah warteg yang banyak dijumpai di pinggir-pinggir jalan raya.

Jika pada segmen bisnis penjual makanan lain terus meningkatkan strateginya untuk memperluas atau justru hanya untuk bertahan, warteg seakan "percaya diri" dengan kondisinya yang demikian. Ada kesan bahwa pengusaha warteg justru ingin melestarikan citra kesederhanaan dan keklasikannya. Dari sisi bisnis, tentunya hal ini sangat disayangkan, mengingat warteg merupakan usaha entry point yang sangat potensial untuk dikembangkan, tanpa harus memer-lukan keahlian khusus dalam bidang entrepreneurship karena produknya merupakan makanan pokok yang cara penyajiannya identik dengan keseha-rian masyarakat Indonesia, terutama Pulau Jawa. Jadi memulai bisnis warteg sangat mudah, dari sisi bahan mentah, produsennya, perencanaan modal bahkan radius dan studi kelayakannya.

Di antara sekian fenomena ekonomikultural menarik tentang warteg, Memiliki kontribusi pengetahuan dan pemahaman sebagai berusaha menjadikan komponen kulturasi budaya media secara cerdas dan bijaksana dalam kehidupan masyarakat (Suryadi, 2013; Rianto, 2016). di Jakarta Selatan, terdapat warteg yang cat dan namanya seragam. Jumlahnya semakin hari semakin meningkat. Warna hijau dan kuning dengan kesan bersih dan dinding yang cerah bertuliskan "Kharisma Bahari" menjadi ciri khasnya. Yang cukup mengejutkan adalah sistem jaringan dari warteg ini menggunakan cara franchise yang selama ini hanya dikenal pada bisnis modern. Tidak hanya itu, di kantor pusat "Kharisma Bahari” justru sudah diujicobakan sistem pembayaran digital untuk memudahkan pembayaran, terutama untuk para pengemudi ojek online.

Penjelasan dari penggagas Franchise "Kharisma Bahari" ternyata sangat visioner. Konsep "Kharisma Bahari" di masa yang akan datang tidak hanya sebatas berhenti pada terjualnya makanan, tetapi akan terus ditingkatkan pada konsep transaksi dan pelayanan yang up to date dan kompetitif, sehingga segmentasi pasar/konsumen dapat diperluas. Tradisi budaya belajar dari nilainilainya dapat dilihat secara pola komunikasi, cara berulang dalam pemikiran, merasa, dan bertindak dengan kata lainnya pilihan kita dan memberikan pedoman perilaku perencanaan (Marini, 2012). Dengan demikian, pedoman perilaku mengandung pesan dengan makna budaya, seakan-akan menimbulkan perilaku (commo sense) (Kriyantono, 2007).

Apakah makna mitos atau fakta Citra warteg sebagai menu kalangan rakyat menengah ke bawah akan terangkat, jika kemudian sistem pemasarannya tidak hanya dilakukan dalam bentuk "warung" saja, tetapi juga merambah pada sistem pemasaran digital. Hal ini tentu menjadi tantangan tersendiri bagi penggagas franchise "Kharisma Bahari", mengingat pengelola warteg rata-rata memang berpendidikan ren-dah. Namun demikian, potensi kemajuan itu sangat terbuka, dengan adanya smartphone, yang sangat mudah mendukung sistem digitalisasi. Pada sisi ini, membicarakan kemajuan warteg menjadi sangat menarik. Hal inilah yang melatarbelakangi peneliti untuk mengetahui lebih mendalam perencanaan dan strategi komunikasi jaringan warteg franchise dalam penelitian ini. 
Terdapat perencanaan komunikasi yang dirancang oleh penggagas jaringan warteg franchise "Kharisma Bahari" demi meningkatkan segmentasi konsumen dan perluasan pemasaran. Terdapat strategi komunikasi yang dirancang oleh penggagas jaringan warteg franchise "Kharisma Bahari" dalam rangka pembinaan anggota jaringan, agar melaksanakan SOP penjualan, berdasarkan standar-standar yang telah disampaikan pada saat kesepakatan pembukaan warung. Target umum dari perencanaan dan strategi komunikasi adalah peningkatan segmentasi konsumen warteg, yang semula identik dengan konsumsi kalangan menengah ke bawah, menjadi pantas untuk semua kalangan. Perencanaan dan strategi komunikasi jaringan juga ditujukan untuk menyambut digitalisasi sistem penjual-an, demi kemajuan bisnis warteg dan tantangan yang tidak dapat dihindari terutama persaingan bisnis di wilayah Jabodetabek.

Adapun urgensi penelitian, sebagai pemahaman praktis perencanaan dan strategi komunikasi, pengembangan bisnis warung makanan, inovasi bisnis dengan memanfaatkan media baru, serta membuka wawasan dan motivasi bisnis bagi pemula atau peningkatan bisnis makanan yang sudah ada. Hal ini sangat strategis, terutama dalam membuka wawasan bisnis para pelaku WTKB.

Tujuan umum penelitian adalah ingin mengetahui perencanaan dan strategi komunikasi jaringan franchise warung tegal Kharisma Bahari dalam meningkatkan segmentasi konsumen. Adapun tujuan khusus adalah ingin mengetahui perencanaan dan strategi komunikasi jaringan franchise warung tegal Kharisma Bahari dalam mengembangkan sistem penjualan berbasis digital untuk meningkatkan segmentasi konsumen.

Ada 3 (tiga) penelitian sebagai "state of the art" yang terkait dengan penelitian ini. Pertama, Ifaloye (2014), pada tesis ini, perencanaan komunikasi pemasaran ini dirancang untuk membuat khalayak sasaran dari pengembangan produk Super Kiddo mengalami peningkatan kesadaran tentang produk makanan sehat di pasar Inggris. Strategi yang diimplementasikan adalah dengan mendorong orang tua untuk menjaga kesehatan dan kesejahteraan anak mereka. Namun, ada motif yang tidak dapat dilepaskan, yakni memaksimalkan keuntungan pemegang saham, menambah portofolio merek dan meningkatkan pangsa pasar dan penjualan. Latar belakang penelitian adalah antisipasi kegagalan perencanaan bisnis terdahulu, akibat manajer terlalu berpikiran bisnis; sehingga mereka melihat biaya kampanye sebagai biaya, bukan investasi. Oleh karena itu, tim kampanye pemasaran Kellogg mengubah paradigma biaya sebagai investasi yang akan diimbangi keuntungan dari pasar makanan ringan Inggris.

Strategi komunikasi pemasaran yang digunakan adalah 3 P's strategi komunikasi, yakni Pull-positioning, Push-Positioning dan Profile-Positioning. Hasilnya adalah melalui pull-positioning, pesan diarahkan ke audiens dengan target tertentu, sehingga mampu memposisikan merek dalam benak mereka dengan mendorong keterlibatan pelanggan, meningkatkan kesadaran dan memotivasi kelompok yang ditargetkan. Push-Positioning dilakukan dengan memaksimalkan kesenangan anak-anak dengan memberikan bonus kemasan bergambar super hero, sedangkan ProfilePositioning dilakukan dengan memaksimalkan semua stakeholders.

Kedua, dari Ida Suryani Wijaya, Dosen Tetap pada Fakultas Ushuluddin, Adab, dan Dakwah IAIN Samarinda, "Perencanaan dan Strategi Komunikasi dalam Kegiatan Pembangunan”, Juni 2015. Dinyatakan oleh Ida Suryani bahwa perencanaan komunikasi menjelaskan bagaimana cara menyebarluaskan pesan yang tepat dari komunikator kepada khalayak yang tepat, melalui saluran yang tepat, dan waktu yang tepat pula. Pengertian strategi komunikasi adalah suatu rancangan yang dibuat untuk mengubah tingkah laku manusia dalam skala yang lebih besar melalui transfer ide-ide baru. Untuk mencapai hasil yang tepat dalam melaksanakan program pembangunan, diperlukan perencanaan dan strategi yang tepat. Penetapan strategi diawali dengan menetapkan 
komunikator, menetapkan target sasaran dan analisis kebutuhan khalayak, menyusun pesan, memilih media dan saluran komunikasi, efek komunikasi.

Sebuah proses komunikasi yang dilaksanakan tidak luput dari berbagai rintangan atau hambatan. Oleh karena itu, perencanaan komunikasi dimaksudkan untuk mengatasi rintangan-rintangan yang ada guna mencapai efektivitas komunikasi, sedangkan dari fungsi dan kegunaan komunikasi perencanaan diperlukan untuk mengimplementaskan program-program yang ingin dicapai. Perencanaan komunikasi dalam kerangka yang sangat sederhana dikaitkan dengan bagaimana menciptakan komunikasi yang efektif. Dalam kerangka yang lebih luas perencanaan komunikasi diperlukan untuk menyusun strategi agar program-program pembangunan yang berskala nasional bisa berhasil.

Ketiga, Lucky Selly Agustin (2016), penelitian ini bertujuan untuk mengetahui dan mendeskripsikan bagaimana strategi komunikasi Dinas Pariwisata, Ekonomi Kreatif dan Kominfo dalam meningkatkan pariwisata di Kota Samarinda. Perolehan data primer melalui key informan dengan wawancara langsung dan observasi, serta dokumentasi: arsip-arsip dan dokumen yang berkaitan.

Dari hasil penyajian data yang diperoleh, wujud dari strategi komunikasi yang ada di Dinas Pariwisata, Ekonomi Kreatif dan Kominfo adalah dengan melakukan berbagai pencapaian perencaan kegiatan dan metodemetode yang digunakan dalam hal meningkatkan pariwisata di Kota Samarinda. Hal tersebut dilakukan dengan adanya komunikasi yang terjalin dengan baik di lingkungan internal dan eksternal instansi. Diketahui pula adanya strategi komunikasi melalui sosialisasi yang merupakan kegiatan untuk menyampaikan, menginformasikan, mengembangkan serta mengarahkan masyarakat tentang pentingnya pariwisata dan sadar wisata. Penggunaan media berupa media massa melalui media televisi, radio, surat kabar (koran), dan media baru internet (website) yang digunakan sebagai jembatan komunikasi untuk menyampaikan pesan dari Dinas Pariwisata, Ekonomi Kreatif dan Kominfo Kota Samarinda kepada masyarakat dan wisatawan baik lokal maupun mancanegara.

Strategi lainnya adalah special event. Hal ini dilakukan dengan mengadakan berbagai kegiatan seperti pameran di tepian Mahakam. Kegiatan ini merupakan agenda penting yang ditujukan untuk menggambarkan pariwisata Kota Samarinda dengan berbagai keragaman dan kelebihannya. Berbeda dengan penelitian yang peneliti lakukan objek penelitian ini merupakan jaringan Franchise Warung Tegal Kharisma Bahari (WTKB) yang tentunya juga memiliki strategi yang berbeda di dalamnya.

Perencanaan pada hakikatnya adalah usaha yang dilakukan secara sadar dan terus menerus serta dikelola untuk memilih alternatif yang terbaik dari berbagai alternatif yang ada untuk mencapai tujuan tertentu (Cangara, 2014:2425). Selebihnya definisi Perencanaan program Komunikasi dapat juga diartikan sebagai upaya membuat rancangan pelaksanaan suatu program komunikasi untuk mengkampanyekan, menyosialisasikan, atau mempromosikan suatu "produk" (program, barang, jasa, atau lembaga) kepada khalayak sasarannya dengan harapan tercapainya tujuan PPK yang telah ditetapkan (Hamad, 2016) Oleh karena itu perencanaan komunikasi dimaksudkan untuk mengatasi rintanganrintangan yang ada guna mencapai efektivitas komunikasi, sedangkan dari sisi fungsi dan kegunaan komunikasi perencanaan diperlukan untuk mengimplemen-tasikan programprogram yang ingin dicapai, apakah itu untuk pencitraan, pemasaran, penyebarluasan gagasan, kerja sama, atau pembangunan infrastruktur komunikasi (Cangara, 2014: 43). Peranan literasi media juga dikatan dapat mengawali proses perencanaan komunikasi dalam perkembangan konten isi dan program media massa yang begitu banyaknya dilihat dari kebutuhan manusia. Sehingga berdampak pada aspek kegunaan media dan penikmat media sebagai hal rencana aksi literasi media yang 
berkaitan pada perencanaan komunikasi tadi. (Yodiansyah, 2017).

Strategi komunikasi adalah kombinasi terbaik dari semua elemen komunikasi mulai dari komunikator, pesan, saluran (media), penerima sampai pada pengaruh (efek) yang dirancang untuk mencapai tujuan komunikasi yang optiomal. (Middleton, (1980) dalam Cangara, 2014: 64). Pemilihan strategi merupakan langkah krusial yang memerlukan penanganan secara hati-hati dalam perencanaan komunikasi, sebab jika pemilihan strategi salah atau keliru maka hasil yang diperoleh bisa fatal, terutama kerugian dari segi waktu, materi dan tenaga. Oleh karena itu strategi juga merupakan rahasia yang disembunyikan oleh para perencana (Cangara, 2014: 65).

Menurut Stohls (2005) (dalam Pearson, 2011: 207), jaringan komunikasi dalam organisasi terbentuk berdasarkan komunikasi formal dan komunikasi informal. Secara umum, terdapat dua macam jaringan komunikasi dalam organisasi yaitu formal dan informal. Jaringan komunikasi formal adalah sistem yang dirancang oleh manajemen untuk menentukan "siapa seharusnya berbicara kepada siapa" agar pekerjaan dapat diselesaikan. Jaringan komunikasi formal organisasi skala kecil lebih sederhana dibandingkan dengan jaringan komunikasi formal organisasi skala besar. Menurut Ronald Adler, et. al. dalam buku Communicating at Work : Strategies for Success in Business and the Professions, terdapat 3 (tiga) macam jaringan komunikasi formal dalam organisasi, yaitu: komunikasi dari atas ke bawah atau downward communication, komunikasi dari bawah ke atas atau upward communication, komunikasi horizontal atau horizontal communication (komunikasi lateral).

Adapun komunikasi informal terdiri dari: 1) conforming - mengkonfirmasi, 2) expanding -menjembatani kesenjangan yang terjadi akibat pesan-pesan formal yang tidak jelas. 3) Expediting -komunikasi informal seringkali dapat mengirimkan pesan lebih cepat daripada saluran formal. 4) Contradicting - komunikasi informal berlawanan dengan pesan-pesan yang bersifat resmi. 5) Circumventing pemangkasan. 6) Supplementing -membuat sebuah pekerjaan dapat dikerjakan secara lebih baik dibandingkan dengan komunikasi formal.

Segmentasi merupakan suatu proses membagi-bagi atau mengelompokkan konsumen ke dalam kotak kotak yang lebih homogen (Kasali, 2001). Segmentasi akan membedakan pembeli berdasarkan segmentasi geografis (keinginan), demografis (kelompok pelanggan), psikografis (karakteristik), dan tingkah laku (Kotler \& Amstrong, 2008). Lebih lanjut pengertian segmentasi menurut Kotler (2003): "Market segmentation is the process of breaking a heterogeneous group of potential buyer into smaller homogeneous groups of buyer, that is with relatively similar buying characteristics or needs". Dengan kata lain, segmentasi pasar merupakan suatu aktivitas membagi atau mengelompokkan pasar yang heterogen menjadi pasar yang homogen atau memiliki kesamaan dalam hal minat, daya beli, geografi, perilaku pembelian maupun gaya hidup.

Adapun Tujuan penelitian ini adalah ingin mengetahui perencanaan dan strategi komunikasi jaringan franchise Warung Tegal Kharisma Bahari (WTKB) dalam meningkatkan segmentasi konsumen.

\section{METODOLOGI}

Tipe penelitian adalah kualitatif, definisi penelitian kualitatif sendiri adalah penelitian yang dimaksud untuk memahami fenomena tentang apa yang dialami oleh subjek penelitian, misalnya perilaku, persepsi, motivasi, tindakan dan lain-lain, secara holistik dan dengan cara deskripsi dalam bentuk katakata dan bahasa, pada suatu konteks khusus. Menurut Moleong (2007: 6), penelitian kualitatif bermaksud untuk memahami fenomena tentang apa yang dialami oleh subjek penelitian, misalnya perilaku, persepsi, motivasi, tindakan, dan lain-lain, secara holistik, pada suatu konteks khusus yang alamiah dan dengan memanfaatkan berbagai metode alamiah. Menurut Bogdan dan Taylor (1975) yang dikutip oleh Moleong (2007: 4), 
metodologi kualitatif adalah prosedur penelitian yang menghasilkan data deskriptif berupa kata-kata tertulis atau lisan dari orangorang dan perilaku yang dapat diamati.

Selanjutnya, David Williams (1995) seperti yang dikutip Moleong (2007: 5) mengemukakan bahwa penelitian kualitatif adalah pengumpulan data pada suatu latar alamiah, dengan menggunakan metode alamiah, dan dilakukan oleh orang atau peneliti yang tertarik secara alamiah. Tujuannya adalah memperoleh gambaran seutuhnya mengenai suatu hal menurut pandangan manusia yang diteliti. Jadi, penelitian kualitatif berhubungan dengan ide, persepsi, pendapat atau kepercayaan orang yang diteliti dan kesemuanya tidak dapat diukur dengan angka.

Metode penelitian adalah deskriptif kualitatif. Peneliti mencari, serta melakukan standar prosedur yang menghasilkan data deskriptif berupa kata-kata tertulis atau lisan dari orang-orang dan perilaku yang dapat diamati (Moleong, 2007: 3). Lebih lanjut, peneliti akan mendeskripsikan perencanaan dan strategi komunikasi komunikasi jaringan franchise "Kharisma Bahari" dengan mendalaminya berdasarkan korelasi teoritis serta membuat pola-pola yang memperjelas dan menyederhanakan fenomena komunikasi yang terjadi berdasarkan gejala-gejala yang ditemukan.

Pengumpulan data terdiri dari data primer dan data sekunder. Data primer adalah data yang diperoleh di lapangan secara langsung dari narasumber (key informan). Data primer didapat melalui survei, pengamatan lapangan (observasi) serta wawancara mendalam. Sedangkan data sekunder diambil oleh peneliti melalui telaah kepustakaan. Data dikumpulkan berdasarkan literatur akademis yang relevan dengan pembahasan, dilengkapi pula dengan tinjauan hasil penelitian atau bahasan ilmiah sejenis.

\section{HASIL DAN PEMBAHASAN \\ Strategi Pull}

Sesuai dengan terminologi kebahasaannya, kata pull berarti "mendekat, melakukan penetrasi sampai menyatu dan dengan kekuatan tertentu menarik objek untuk keluar dari posisi semula". Gambaran ini cukup mewakili strategi komunikasi jaringan Warung Tegal Kharisma Bahari (WTKB) pada langkah awalnya. Penggagas WTKB berusaha mengenalkan diri, menawarkan kerja sama dan stimulasi keuntungan, melakukan komunikasi persuasi sekaligus couching, agar ada efek delta, yakni dari kondisi awal menuju kondisi moderasinya.

Pada tahapan pull, penggagas WTKB tidak banyak mengulas tantangan dan tuntutan, tapi lebih banyak membahas kebutuhan. Sebagaimana kultur masyarakat bisnis kalangan bawah, maka permodalan menjadi masalah utama. Dalam hal ini, penggagas WTKB banyak melakukan sosialisasi, agar para pelaku WTKB melengkapi dokumendokumen standar yang dibutuhkan sebagai pengajuan pembiayaan. Usaha ini juga tidak sepenuhnya mudah, maka penggagas WTKB memperbanyak strategi pesan stimulus, tentang hal-hal yang dikawatirkan, misalnya: penagihan, jaminan, cicilan dan sejenisnya.

Dunia eksternal memang banyak diwarnai oleh hegemoni kultural yang sangat jamak. Meskipun dianggap minor, tantangan agama terkadang juga menjadi masalah, misalnya keyakinan para pelaku anggota jaringan WKTB yang tidak bersedia usahanya berkaitan dengan permasalahan riba. Dalam hal ini penggagas WTKB justru berusaha membuat program kerja sama bagi hasil yang memenuhi aturan bisnis yang islami dalam bentuk franchise tadi.

Pada strategi ini, WTKB banyak bersiasat dengan stimulus - respon. Peluang yang dianggap WTKB sangat mendukung adalah sebagian besar mereka, para anggota, ingin mengembangkan usahanya. Meskipun belum banyak berbicara tentang marketing, penggagas WTKB sudah memberikan stimulus berupa fasilitas permodalan. Memang pada langkah ini masih dirasakan sangat konvensional, tetapi penggagas WTKB menyadari bahwa masih banyak kalangan anggota yang memang belum dapat menerima kenyataan berupa perubahan, dari awalnya hanya bekerja kemudian diubah 
sistem bisnis menjadi pengelola yang lebih bertanggung jawab.

Dalam tahapan ini juga digunakan strategi perluasan informasi. Seperti terdapat kebutuhan menu di daerah tertentu yang kemudian disampaikan oleh penggagas WTKB kepada para anggota secara langsung. Hal ini tidak semata-mata ditujukan untuk perluasan distribusi semata, tetapi juga target WTKB ingin memberikan stimulus berupa kualitas produk yang diminta. Meskipun tidak semua target dapat dibidik secara maksimal, tetapi sebagian target kemudian merasa perlu meningkatkan variasi menu mereka untuk memenuhi permintaan. Didorong pula adanya words of mouth. Yang dimaksud adalah sosialisasi yang bukan dilakukan oleh penggagas WTKB, tetapi dilakukan oleh para anggota WTKB sendiri. Dalam setiap kesempatan, para pelaku WTKB diundang atau dibina dalam kegiatan tertentu, WTKB juga menghimbau adanya upaya-upaya tiap anggota untuk terus mensosialisasikan programprogram, kegiatan-kegiatan, ataupun informasiinformasi yang dapat disampaikan pada para pelaku WTKB yang lain.

\section{Strategi Push}

Sesuai dengan peristilahannya, makna push merupakan dorongan agar ada efek pacu, yang targetnya tidak hanya kapasitas tetapi juga daya saing. Dapat diklasifikasikan bahwa untuk anggota potensial yang dimungkinkan bergabung dalam jaringan, penggagas WTKB (yang kemudian sudah menjadi Manajemen WKTB) masih melakukan strategi pull. Sebaliknya, untuk anggota yang sudah beroperasi bisnisnya, Manajemen WTKB melakukan strategi push.

Ditinjau dari konteksnya, strategi ini banyak dipangaruhi oleh isu-isu terkini fenomena bisnis yang ekstrim, misalnya tutupnya restoran dan usaha makanan lainnya, penurunan drastis jumlah penjualan, pesaing yang tidak lagi menawarkan kualitas lebih baik tetapi juga harga lebih murah. Fenomenafenomena negatif ini yang dijadikan pengelolaan pesan oleh Manajemen WTKB dalam melakukan strategi push. Terlebih lagi isu-isu kebangkrutan itu mengerucut pada persoalan adanya kemiskinan inovasi dan kreasi, sebaliknya banyaknya bisnis yang ternyata mampu bertahan karena memiliki daya adaptif berupa kreativitas dan inovasi. Pesanpesan ini tentu saja sangat membantu strategi push agar timbul kesadaran bahwa kenyamanan merupakan ancaman bagi pelaku pelaku makanan sekelas warung tegal.

Di antara pesan lainnya, isu perubahan menjadi hal yang sangat menarik untuk terus disampaikan. Di samping sudah banyak tersampaikan dalam banyak forum, isu perubahan sangat menyadarkan para pelaku WTKB yang merasa berada pada area comfort zone. Etos 5R menjadi target utama Manajemen Jaringan WTKB, yaitu Ringkas, Rapi, Resik, Rawat dan Rajin. Konsep ini meskipun sudah banyak dikenal, tetapi sebagai prinsip usaha, sangat disadari WTKB masih menjadi daya saing yang cukup serius di kalangan usaha kecil. Dalam jaringan warung franchise WTKB, sebenrnya pertaruhan utama ada pada masalah kerapihan dan kebersihan. Jika hal ini tercapai, maka upaya "menaikkan" segmentasi konsumen mereka dari warung kelas bawah menuju kelas menengah akan tercapai.

Sepintas kehadiran WTKB sejenis Kharisma Bahari sangat menggembirakan, mengingat warung tegal yang selama ini menjadi usaha kuliner kalangan bawah mampu bertahan dari berbegai terpaan segala kondisi dan dinamika perekonomian nasional maupun global, namun ironisnya mereka masih tidak beranjak dari segmentasi kalangan bawah.

Di lain pihak fenomena $5 \mathrm{~S}$ yang menjadi target utama jaringan warung tegal seperti yang peneliti sebutkan masih harus diakui belum maksimal, bahkan menurut beberapa kalangan konsistensinya justru berpotensi menurun. Hal ini didasarkan pada klaim BPOM yang banyak mendapati banyak standar kesehatan usaha warung tegal yang memang masih sangat minim standarisasi dan WTKB masih mengalami kesulitan untuk mencanangkan programnya ke arah itu, meskipun sebenarnya banyak sekali warung tegal yang 
pendapatannya memenuhi syarat bahkan melampaui persyaratan anggota binaan BPOM. Walaupun demikian, konten yang berulangulang disampaikan dalam berbagai kesempatan, setidaknya banyak warung tegal yang justru menawarkan kebersihan, kesehatan atau higienisitas sebagai slogan yang dicantumkan pada papan nama. Sayangnya untuk anggota WTKB masih minor.

Apa yang disampaikan Manajemen WTKB dalam strategi push dalam konteks umum memang hanya diarahkan pada hal-hal perubahan yang dapat dikategorikan sebagai seeing is believing, demikian peristilahan yang digunakan. Maksudnya adalah dengan melihat secara langsung bukti-bukti kekurangan warung tegal, para pelaku WTKB dapat melihat bahwa ancaman disrupsi itu memang ada dan terjadi.

Pada tahapan yang lebih spesifik, strategi push juga dilakukan dengan seeing adanya kemajuan teknologi yang menjadi tantangan sekaligus tuntutan. Betapa banyak mereka yang tidak hanya mengandalkan konsumen yang datang, tetapi juga konsumen yang jaraknya jauh. Terobosan teknologi ini harus disadari oleh semua pelaku WTKB, karena potensi kapasitas dan peluang sangat menjanjikan, tetapi bagi mereka yang berkehendak menggunakannya. Sebaliknya bagi mereka yang tidak merespon hal ini, dapat dipastikan lokalitas pemasarannya semakin terbatas. Jika hal ini tidak ditanggapi sebagai ancaman, maka harus dianggap sebagai peluang.

Bagi sebagian pelaku WTKB memang teknologi, meskipun di antara sekian banyak para pelaku usaha sudah memiliki smartphone, tetapi untuk beranjak menaikkan kapasitas ataupun berinovasi menggunakannya, masih dirasakan WTKB menjadi tantangan yang tidak ringan. Bagi WTKB yang sudah menengah, daya serap mereka terhadap berbagai hal baru cukup menggembirakan, tetapi pada WTKB lapisan bawah masih saja terdapat penolakan, atau setidaknya menganggap terobosan teknologi sebagi hal yang merepotkan.

Dalam koordinasi organisasi, pihak Manajemen WTKB terus melakukan identifikasi tantangan dan tuntutan dari pengembangan kapasitas jaringan WTKB. Seperti halnya pada strategi pull, pada strategi push juga terdapat proses legitimasi dan institusionalisasi. Dalam tahapan ini legitimasi lebih banyak dikelola berdasarkan wacana disrupsi yang pengelolaannya berbeda dari strategi umum, yakni mendorong kapasitas bisnis. Disrupsi pada tahapan ini lebih banyak diarahkan pada konsep MSDM terhadap peluang disrupsi dengan pemahaman bahwa disrupsi di masa lampau adalah fenomena persaingan bisnis yang banyak mematikan sektor WTKB, seperti kehadiran supermarket, tetapi yang ingin dipahamkan oleh WTKB adalah sebuah realitas bahwa bisnis skala besar itu kini dikalahkan oleh bisnis-bisnis skala kecil. Hal ini selaras dengan publikasi pemerintah bahwa WTKB adalah UMKM yang merupakan soko guru perekonomian nasional.

Legitimasi ini disampaikan dengan dasardasar yang memang terjadi semenjak adanya media baru yakni internet. Bisnis online yang demikian marak dan masif terbukti membuat kerangka bisnis besar, seperti Hero, SevenEleven, Glodok dan banyak lagi, mengalami gulung tikar. Hal ini disebabkan oleh penyelenggaraan bisnis yang tidak lagi banyak dipengaruhi oleh tempat dan etalase, tetapi sangat dipengaruhi oleh inovasi dan kreativitas yang visual saja dengan memanfaatkan jaringan. Bangunan bisnis yang besar di dunia maya sangat mungkin dimiliki oleh pelaku yang sama sekali tidak memiliki bangunan fisik. Kesadaran ini menjadi pesan yang sangat sesuai untuk membangun kapasitas bisnis para pelaku WTKB dalam meningkatkan segmentasi konsumen.

Selanjutnya Manajemen WTKB tidak hanya melakukan sosialisasi tetapi juga pembinaan praktis, dengan bukti-bukti nyata peningkatan pendapatan para pelaku WTKB yang banyak menggunakan pemasaran digitalnya. Dari sisi keanggotaan, hal ini juga sangat berkontribusi pada peningkatan jumlah anggota WTKB, terlebih lagi WTKB juga membantu membuat link jaringan pemasaran antar WTKB agar terjadi silang bisnis dengan 
lobi dan negosiasi yang lebih ekonomis. Legitimasi peningkatan kapasitas bisnis digital juga dimediasi WTKB dengan melakukan lintas komunikasi dengan para pengusaha rumahan lain.

Sebagaimana strategi pull yang juga memaksimalkan kompetensi para pelaku WTKB sendiri dalam mensosialisasikan program-program WTKB, pada strategi push, para pelaku WTKB dibuatkan forum sharing. Forum sharing ini tidak hanya terjadi pada Whatsapp Group, tetapi juga melalui forum komunikasi family gathering WTKB.

\section{Strategi Pass}

Definisi pass strategy dalam penelitian ini tidak jauh berbeda dengan teori Kotler (dalam Rosady Ruslan, 2010: 2), yaitu sebagai upaya mempengaruhi atau menciptakan opini publik yang menguntungkan melalui berbagai kegiatan, partisipasi dalam kegiatan kemasyarakatan, tanggung jawab sosial serta kepedulian masalah yang berkaitan dengan kondisi dan lingkungannya. Mendukung pula pendapat Saka, (1994: 99), pass strategy adalah strategi yang digunakan untuk mempengaruhi gatekeeper orang ketiga agar mendukung dan mendorong publik untuk ikut terlibat dalam kegiatan WTKB.

Dalam strategi ini, WTKB memberikan diskon untuk para pengemudi online, ada santunan Dhuafa, berupa makan gratis di hari Jum'at, serta menjalin kerja sama dengan Dompet Dhuafa, melalui kotak amal yang disediakan, serta dari keuntungan WTKB sendiri. Pihak Manajemen WTKB tidak hanya berusaha mendorong para anggota untuk mengandalkan upaya dari bisnis saja tetapi juga dari citra masyarakat, sehingga diharapkan konsumen tidak hanya membeli makanan tetapi ada citra ikut andil dalam kegiatan beramal dan shodaqoh.

Adapun hambatan-hambatan komunikasi yang ditemukan oleh peneliti dalam proses penelitian tersebut meliputi hambatanhambatan yang terjadi selama implementasi strategi pull dan push komunikasi bisnis sebagai berikut:

\section{Hambatan Pendidikan}

Hambatan ini masih menjadi kendala klasik, karena banyak pelaku WTKB kelas menengah yang sudah memiliki karyawan cukup banyak dan omset jutaan rupiah perhari, yang pengelolaannya masih konvensional. Meskipun secara operasional, usaha yang dijalankan masih stabil dan terkesan tidak menemui kendala berarti, tetapi pengelolaan administrasi bisnis yang tidak sebagaimana mestinya membuat perhitungan terhadap sarana dan prasarana cukup ironis. Masih didapati pelaku usaha kuliner yang memilki beberapa mobil operasional tetapi tidak dapat dikuantifikasikan bagaimana penyusutan, pemilahan aset bisnis dan aset pribadi. Hal ini diperparah jika pengetahuan pengelolanya tidak sampai pada identifikasi perubahan eksternal. Jika dianggap siklus bisnis sebagai sebuah realita, maka pada titik tertentu, usaha ini akan menemui ujian. Jika siklus penurunan itu terjadi dengan tajam, maka perhitungan aset menjadi sangat sulit.

\section{Hambatan Budaya}

Hambatan ini dianggap paling dominan oleh WTKB. Indikasinya adalah target bisnis hanya untuk pemenuhan hidup, sedangkan inovasi dan kreasi dianggap sebagai beban, tantangan dan tuntutan menimbulkan kepasrahan. Akhir keberhasilan adalah upaya menjual produk sampai habis, dan persoalan dianggap selesai.

Di samping itu, kultur komunikasi yang menganggap hari merupakan pengulangan saja, yang jika gagal hari ini kemungkinan besok tidak terulang kembali, atau masih ada kesempatan hari esok. Hal ini berbeda dengan mereka yang budayanya sudah maju, bahwa hari ini adalah kesempatan yang hanya sekali, sehingga apa yang bisa dikerjakan hari ini harus segera mungkin, sehingga perubahanperubahan kecil itu dapat terjadi. Jadi, ada budaya yang tidak responsif terhadap perubahan, sehingga pelaku bisnis yang dimaksud sulit beradaptasi, dan pada suatu titik ketika penjualan terus menurun, dapat dengan 
cepat beralih ke usaha lain, dengan menjual seluruh aset.

\section{Hambatan Personal}

Hambatan personal ini terjadi pada sisi pelaku pemula dalam jaringan WTKB, di antaranya ada hambatan prasangka, stereotip dan bias. Masih terjadi saling kecurigaan dan ketidaknyamanan ketika pihak Manajemen kemudian melakukan sidak atau pemantauan. Alasan beberapa pelaku adalah urusan mereka sebatas bagi hasil saja, yang seharusnya tidak perlu terlalu jauh untuk dikritik. Hal lain adanya stereotip bahwa pebisnis merupakan bidang profesi yang pranata sosialnya lebih tinggi, apalagi dengan isu yang digulirkan, yaitu digitalisasi.

\section{SIMPULAN}

Berdasarkan hasil penelitian dan pembahasan yang telah peneliti jabarkan diatas, strategi komunikasi jaringan WTKB dalam meningkatkan segmentasi konsumen, pada tahapan awal sejak WTKB berdiri sampai dengan menjelang maraknya penggunaan media baru dalam bidang pemasaran, maka ditemukan bahwa strategi komunikasi bisnis yang digunakan adalah model pull. Model ini difokuskan pada pengembangan rintisan usaha WTKB sekaligus peningkatan sumberdaya WTKB, meskipun dari sisi teknis, unsur tantangan dan tuntutan teknologi belum menjadi target peningkatan kapasitas sumberdaya manusia secara langsung. Sejak tuntutan dan tantangan daya saing tidak terhindarkan lagi, diperkuat oleh fenomenafenomena disrupsi bisnis di berbagai lapisan, terutama di lapisan bisnis berskala besar, strategi komunikasi jaringan push digunakan sebagai upaya peningkatan sumberdaya pelaku WTKB secara langsung. Maksud secara langsung adalah target inovasi dan kreativitas bisnis bagi pelaku WTKB, yang sebelumnya hanya ditargetkan pada peningkatan kemampuan kuantitas komoditi yang dihasilkan. Strategi push ini juga menjadi inspirasi WTKB dalam memperluas mitra informasi bisnis WTKB, karena tuntutan daya saing yang tidak lagi dapat dihindari, akibat penggunaan internet yang tidak terbatas dan tidak dapat dibatasi.

Strategi pengelolaan pesan pada tahapan implementasi komunikasi jaringan pull, dapat dianalogikan dengan istilah "jemput bola". WTKB menampung semua aspirasi dan inspirasi para pelaku WTKB untuk dicarikan jalan keluar pengembangannya.

Sementara itu strategi komunikasi jaringan pass dilakukan dengan sikap empatik pada para pengemudi ojek online, para dhuafa, bahkan menjalin ikatan dengan lembaga pemerhati dhuafa. Hal ini tentu sangat kondusif meningkatkan kesan masyarakat atau konsumen terhadap keberadaan WTKB, yang tidak hanya memusatkan diri pada bisnis warung tetapi juga ada kampanye untuk peduli sesama dalam menjalankan bisnis.

Adapun faktor-faktor penghambat dalam mengimplementasikan bentuk-bentuk strategi komunikasi jaringan WTKB adalah hambatan komunikasi budaya. Budaya pelaku WTKB yang memandang bisnis hanyalah persoalan jual beli, asal didapatkan keuntungan, menjadi hambatan kemajuan. Selanjutnya terdapat hambatan pendidikan. Tingkat pendidikan menentukan wawasan dalam melihat perubahan, tantangan dan tuntutan. Mereka yang banyak berkegiatan di kampus tentu akan banyak mendapatkan informasi, kajian, seminar, pengetahuan, sehingga mereka lebih adaptif dalam melihat keberlangsungan bisnis demikian pula dalam mengomunikasikan ideidenya. Ada pula hambatan personal. Sisi personal yang kritis negatif terhadap kehadiran WTKB bahkan kebijakan perbankan juga menjadi penghambat.

Di lain pihak, hal-hal yang mendukung strategi pull dan push dalam peningkatan segmentasi konsumen WTKB adalah menu WTKB yang memiliki strong brand kuliner kedaerahan, serta positioning "murah" bagi kalangan masyarakat secara mayor. Adapun hal-hal yang tidak mendukung adalah segmentasi konsumen warteg dan brand warteg yang masih melekat pada konsumsi masyarakat menengah ke bawah. 


\section{DAFTAR PUSTAKA}

Bungin, B. (2013). Penelitian Kualitatif. Jakarta: Prenada Media Group

Cangara, H. (2014). Perencanaan dan Strategi Komunikasi. Jakarta: RajaGrafindo Persada.

Fill, C. (2009). Marketing Communications: Interactivity, Communities and Content Fifth Edn. Essex: Pearson

Fill, C. (2013). Marketing Communications Brands, Experiences and Participation Sixth Edition. Harlow: Pearson

Hamad, I. (2016), Modul Pembelajaran Perencanaan Program Komunikasi, Universitas Terbuka.

Ifaloye Emmanuel, Oluwaseun. (2014). Journal Oluwaseun University of Kent, "Marketing Communications Plan: Kelloggs Healthy snack bar for Children (Super Kiddo)"

Kotler, P. (2003). Manajemen Pemasaran. Edisi kesebelas, Jakarta: Indeks kelompok Gramedia.

Suryadi, I. (2013). Kajian Perilaku Menonton Tayangan Televisi dan Pendidikan Literasi Media pada Remaja, ISSN 1411- 3341. article, 5(1), pp.973-986.

Uchjana, O. (2013). Ilmu Komunikasi Teori dan Praktek. Bandung: PT. Remaja Rosdakarya.

Wijaya Suryani, Ida. (2015). Perencanaan dan Strategi Komunikasi Dalam Kegiatan
Kotler, P., \& Keller, K. L. (2009). Manajemen Pemasaran. Penerbit Indeks, Jakarta.

Kriyantono, R. (2007). Pemberdayaan Konsumen Televisi Melalui Keterampilan Media - Literacy dan Penegakan Regulasi Penyiaran. article, 10(21).

Marini, A. (2012). Jurnal Ilmiah PGSD; Penerapan Pembelajaran Berbasis Teknologi Informasi Untuk Meningkatkan Hasil Belajar mahasiswa. article, 4(1).

Moleong, L. J. (2007). Metode Penelitian Kualitatif, Edisi Revisi. Bandung: PT.Remaja Rosdakarya.

Rianto, P. (2016). Media Baru, Visi Khalayak Aktif dan Urgensi Literasi Media. article, 1(2), pp.90-96.

Schiffman dan Kanuk. (2008). Perilaku Konsumen. Edisi 7. Jakarta: Indeks.

Setiadi, N. J. (2003). Perilaku Konsumen: Konsep dan Implikasi untuk Strategi dan Penelitian Pemasaran. Prenada Media, Jakarta.

Pembangunan. Jurnal LENTERA, 17(1).

Yodiansyah, H. (2017). “Akses Literasi Media Dalam Perencanaan Komunikasi, JURNAL IPTEKS TERAPAN Research of Applied Science and Education V11.i1 (128 - 155) 